\title{
Testosterone and corticosterone co-regulate messenger RNA coding for secretory proteins in the epididymis of the lizard (Lacerta vivipara)
}

\author{
Y. Courty* \\ Biologie cellulaire, Université Blaise Pascal, et CNRS URA 360 24, Av. des Landais, 63170 \\ Aubière, France
}

\begin{abstract}
Summary. The hormonal requirements for the regulation of Lv132 mRNA coding for two proteins secreted by the principal cells of the lizard epididymis were examined by organotypic culture experiments. Testosterone, R1881 and corticosterone induced accumulation of Lv132 mRNA in explants from lizards castrated immediately after differentiation of the principal cells. The induction by testosterone was inhibited by the addition of cyproterone acetate. Progesterone and oestradiol alone or in presence of testosterone were ineffective. Unlike the induction by testosterone, the effect of corticosterone did not require binding on the androgen receptor as shown by competition binding studies. Corticosterone failed to induce gene expression in organs containing only reserve cells in their epithelium at the onset of the culture. However, corticosterone plus testosterone had a synergistic effect. These data suggest that testosterone promotes the differentiation of principal cells from reserve cells during the culture time and that a primary action of testosterone is necessary to confer corticosterone responsiveness on this tissue. Furthermore, the primary effects of testosterone could be memorized by the tissue because the corticosterone responsiveness persists after castration.
\end{abstract}

Keywords: epididymis; secretory proteins; androgen; corticosteroid; cell differentiation; lizard

\section{Introduction}

Mammalian spermatozoa acquire the capacity to fertilize ova during transit through the epididymis. This process, called sperm maturation, is dependent on androgens and requires protein synthesis (Orgebin-Crist \& Jahad, 1978; Cuasnicu et al., 1984; Moore \& Hartman, 1986). In numerous species, major secretory proteins have been isolated and some of them interact with spermatozoa (Voglmayr et al., 1982; Brooks \& Tiver, 1983; Klinefelter \& Hamilton, 1985), and interaction with epididymal secretory proteins can change sperm function (Brandt et al., 1978; Thomas et al., 1984; Turner \& Reich, 1987). Several studies have examined the effects of androgens on the epididymis in adult mammals, but control of the differentiation process leading to a selective and highly controlled expression of the genes encoding secretory proteins remains unknown. It has been suggested that non-androgenic factors may be involved in some differentiation processes in the prepubertal epididymis (Toney \& Danzo, 1989; Charest et al., 1989).

At birth, the epididymis of mammals is formed of transitional cellular elements. The terminal differentiation of these cells takes place post-natally (Sun \& Flickinger, 1979; Abou-Aila \& FainMaurel, 1986). A similar situation is observed in the viviparous lizard during the reproductive

*Present address: Institut Pasteur, Unité de Génétique et Biochimie du développement, 28 rue du Docteur Roux, 5724 Paris, France. 
cycle. At stages 5 and 6 (Dufaure et al., 1986), hypertrophied principal cells produce large secretory granules containing L-proteins $\left(M_{\mathrm{r}} 19000\right.$ : Depeiges \& Dufaure, 1981; Depeiges et al., 1988). These proteins interact with the membrane of the sperm head (stage 6; Depeiges \& Dufaure, 1983), and the spermatozoa then mature in the epididymis (Depeiges \& Dacheux, 1985) as in mammals. The expression of the L-genes is specific to principal cells (Depeiges et al., 1981) and is first detected at stage 1, showing that principal cells are differentiated at this stage (Courty et al., 1989). At stage 2, the number of principal cells is greatly enhanced while some reserve cells remain at the base of the epithelium. The principal cells become secretory starting from stage 3 and mature until stage 6 (Dufaure et al., 1986; Ravet et al., 1987). After the mating period of the lizard, the principal cells degenerate (stages $7,8,9$ ) and the reserve cells form a new epithelium (stage 10). The intraepididymal concentrations of testosterone are minimal at stage 10 , increase at stage 1 and after stage 3, reaching their maximal values at stage 6 . The expression of genes coding for L-proteins parallels the intra-epididymal concentrations of testosterone (Courty et al., 1989). The proliferative phase persists after castration at stage 1; furthermore, androgen deprivation at stage 3 does not impair the second rise of gene expression which continues up to 15 days after gonadectomy. These observations suggested a multifactorial regulation of the lizard epididymis (Morel et al., 1986).

In the present study, we have examined regulation of the Lv132 mRNA coding for two L-proteins, by determining whether various steroid hormones are involved in the expression of this mRNA in epididymides from lizards castrated immediately after the differentiation of principal cells (stage 1). As corticosterone induced the Lv132 mRNA accumulation, we have tested its effects on epididymides containing only reserve cells in the epithelium (stage 10) at the onset of culture.

\title{
Materials and Methods
}

\begin{abstract}
Animals. Common north European lizards (Lacerta vivipara) were captured in the Massif central (France) during July and August. Castration was performed via the abdominal route following ether anaesthesia. Animals were killed by decapitation. The adrenal gland, which is close to the epididymis, was dissected out before removal of the epididymis. For each lizard, a piece of the median part of one epididymis was fixed in Bouin-Hollande fluid (with $10 \%$ saturated

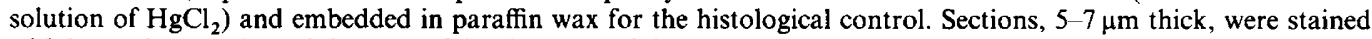
with haemalum-eosin and the state of development of the epithelium was determined according to stages of reference previously described (Dufaure et al., 1986).
\end{abstract}

Organ cultures. Pieces $\left(6 \mathrm{~mm}^{3}\right)$ of epididymides from lizards with epithelium at stage 10 or from lizards castrated at stage 1 and killed 1 month later were transferred onto lens paper strips on steel grids in Petri dishes (1 epididymis/ dish). For each condition of one experiment, 6 epididymides were separately cultured. The culture medium was Medium 199 complemented with Earle's salts (Institut Pasteur, Paris, France) containing G-penicillin (30 mg/l), streptomycin $(50 \mathrm{mg} / \mathrm{l})$ and L-glutamine $(100 \mathrm{mg} / \mathrm{l})$. The medium was supplemented with $10 \%$ charcoal-treated (Morel et al., 1988) calf serum (Gibco-BRL, Cergy-Pontoise, France). The Petri dishes were kept in a $\mathrm{CO}_{2}$ incubator $\left(5 \% \mathrm{CO}_{2}\right.$ in air) at $30^{\circ} \mathrm{C}$. The medium was renewed every 2 days and the cultures were continued for up to 10 days. All steroids were purchased from Sigma (St Louis, MO, USA), except for R1881 which was from New England Corporation (Boston, MA, USA). Steroids were dissolved in a small volume of propylene glycol (Flucka AG, Buchs, Switzerland) and then added to the medium at a concentration of 0 to $10^{-7} \mathrm{M}$; the final concentration of propylene glycol was $1 \mu \mathrm{l} / \mathrm{ml}$ medium.

RNA dot blot analysis. Total RNA was prepared from explants corresponding to 6 epididymides, using a monothiocyanate procedure (Cathala et al., 1983). The RNA pellets were dissolved in $10 \%$ formaldehyde, $10 \times$ SSC $\left(1 \times \mathrm{SSC}\right.$ is $0.15 \mathrm{M}-\mathrm{NaCl} ; 0.015 \mathrm{M}$-sodium citrate, $\mathrm{pH}$ 7). Samples were heated for $15 \mathrm{~min}$ at $50^{\circ} \mathrm{C}$ and chilled on ice. RNA was spotted using a dot-blot manifold (Gibco-BRL) onto a nitrocellulose sheet previously equilibrated in $10 \times$ SSC. After sample application, nitrocellulose was baked at $80^{\circ} \mathrm{C}$ for $2 \mathrm{~h}$. Filters were prehybridized and hybridized in $50 \%$ formamide, $20 \mathrm{~mm}$-sodium phosphate $\mathrm{pH} 6.5,5 \times \operatorname{SSPE}(1 \times \operatorname{SSPE}=180 \mathrm{~mm}-\mathrm{NaCl}, 10 \mathrm{~mm}$ sodium phosphate $\mathrm{pH} 7.5,1 \mathrm{mM}-\mathrm{EDTA}), 1 \times$ Denhart $(0.02 \%$ Ficoll, $0.02 \%$ polyvinylpyrolidone, $0.02 \%$ bovine serum albumin) and $0 \cdot 1 \%$ SDS. Pre-hybridization was for $4 \mathrm{~h}$ and hybridization was overnight at $42^{\circ} \mathrm{C}$. Filters were washed twice for $30 \mathrm{~min}$ in $2 \times \mathrm{SSPE}$ at $65^{\circ} \mathrm{C}$, in $1 \times$ SSPE- $-1 \%$ SDS and in $0.5 \times$ SSPE- $0.1 \%$ SDS. Filters were exposed to Kodak X-Omat films at $-80^{\circ} \mathrm{C}$ in the presence of intensifying screen for $12-72 \mathrm{~h} .{ }^{32} \mathrm{P}$-labelled probes were generated from LvI15 and Lv132 plasmids by nick-translation using [ ${ }^{32}$ P]ATP (Amersham France, Les Ulis, France). The specific activity of probes was $1-5 \times 10^{8} \mathrm{~d} . \mathrm{p} . \mathrm{m}$. $/ \mu \mathrm{g}$ DNA. The Lv132 clone contains a 350 base pair insert homologous to one mRNA species coding for an L-preprotein giving two mature L-proteins after post-translational modifications. To determine whether equal amounts of RNA were loaded, dot blots that had been hybridized with 
Lv132 cDNA probe were washed at $65^{\circ} \mathrm{C}$ in $10 \mathrm{~mm}$-phosphate-50\% formamide for $1 \mathrm{~h}$ and hybridized with Lv 115 cDNA probe. This cDNA is homologous to an epididymal mRNA not affected by the hormonal environment. Autoradiographs from various times of exposure were scanned on a LKB laser densito-meter (Ultroscan XL).

Androgen-receptor assay. Androgen receptor concentrations in lizard epididymal tissue were measured as previously described (Veyssiere et al., 1985). Briefly, epididymides at stage 6 were pulverized after freezing in liquid nitrogen and the powder obtained was homogenized in 5 volumes of Buffer A (50 mM-Tris-maleate pH 7.5 ; $1 \mathrm{~mm}-$ DTT; 1 mM-sodium azide; $0.25 \%$ gelatin) in the presence of $0.5 \mathrm{~mm}$-PMSF (phenylmethylsulphonyl fluoride). Three samples were removed for DNA assay and the remaining homogenate was diluted (v/v) in Buffer A40 (Buffer A with $40 \mathrm{~mm}$-sodium molybdate and $3 \mathrm{~mm}$-EDTA pH 7.5). The cytosol fraction (about $6 \mathrm{mg}$ protein/ml) was obtained by a centrifugation at $105000 \mathrm{~g}$ for $60 \mathrm{~min}$ at $2^{\circ} \mathrm{C}$. Samples $(150$ or $200 \mu \mathrm{l})$ of cytosolic fraction were incubated with increasing concentrations of $\left[{ }^{3} \mathrm{H}\right] \mathrm{R} 1881(0 \cdot 1-20 \mathrm{nM}$; sp. act. $87 \mathrm{Ci} / \mathrm{mmol}$ : New England Nuclear Corp.) in the presence or absence of a 100 -fold excess of radioinert $\mathrm{R} 1881$. The incubation was performed for $18 \mathrm{~h}$ at $4^{\circ} \mathrm{C}$ with constant shaking in the presence of $5 \mu \mathrm{M}$-triamcinolone acetonide to inhibit binding of $\left[{ }^{3} \mathrm{H}\right] \mathrm{R} 1881$ to glucocorticoid and progesterone receptors. After incubation, the homogenate was separated into two fractions, the former was used to determine the radioactivity of total homogenate by scintillation counting. The latter was used to separate bound and free fractions using the hydroxylapatite (HAP) method (Hechter et al., 1983).

\section{Results}

Testosterone and R1881 stimulated the accumulation of Lv132 mRNA in explants from lizards castrated at stage 1 (Fig. 1; Table 1). R1881 at $10 \mathrm{~nm}$ elicited a great accumulation of the Lv132 mRNA, but testosterone at the same concentration had a smaller effect. At concentrations higher than $100 \mathrm{nM}$, testosterone had an inhibitory effect; with R1881, this effect was less pronounced (Table 1).

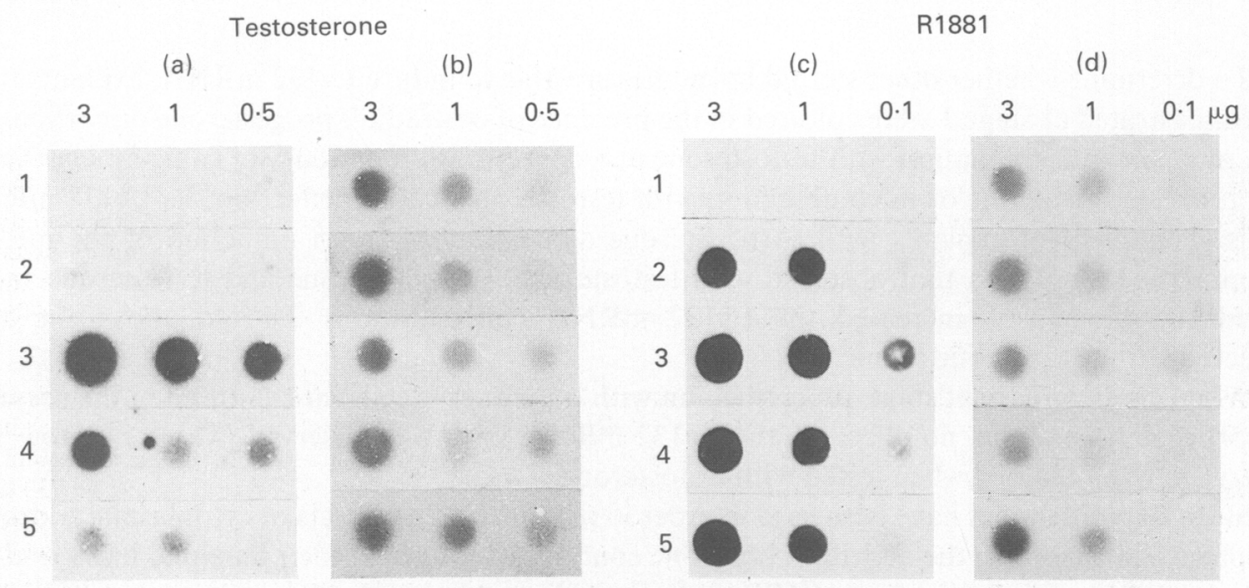

Fig. 1. Effect of androgens on the expression of Lv132 mRNA. Epididymides from lizards castrated at stage 1 and killed 1 month later were cultured for 10 days in the presence of various concentrations of testosterone or R1881. Total RNA was isolated and decreasing amounts were immobilized onto nitrocellulose, hybridized with nick-translated Lv132-DNA probe (a, c) and subjected to autoradiography. The dot blots were washed as described in 'Materials and Methods' and hybridized with ${ }^{32}$ P-labelled Lv115-DNA to verify the RNA loading (b, d). (a, b) 1 , control without steroid hormone; $2,3,4,5,10 \mathrm{nM}-, 100 \mathrm{nM}-, 500 \mathrm{nM}-$ and $1 \mu \mathrm{M}$-testosterone respectively; (c, d) 1, control without steroid hormone; 2, 3, 4, $10 \mathrm{nM}-, 100 \mathrm{nM}-$ and $1 \mu \mathrm{M}-\mathrm{R} 1881$ respectively; 5, 100 nM-testosterone.

Increasing concentrations of cyproterone acetate inhibited progressively the Lv132 mRNA accumulation which represented only $48 \cdot 7,8 \cdot 8$ and $<1 \%$ of the maximal induction when $0 \cdot 1,1$ and $10 \mu \mathrm{M}$ cyproterone acetate were added respectively. As cyproterone acetate is an antiandrogen acting through the androgen receptor, the effect of testosterone on the Lv132 mRNA implies an androgen receptor-dependent mechanism. 
Table 1. Lv132 mRNA accumulation in androgen-treated explants of lizard epididymis

\begin{tabular}{rcc}
\hline \multirow{2}{*}{$\begin{array}{l}\text { Dose } \\
\text { (nM) }\end{array}$} & \multicolumn{2}{c}{$\%$ Maximal induction with: } \\
\cline { 2 - 3 } & Testosterone & R1881 \\
\hline 0 & 0 & 0 \\
10 & 3.5 & 64 \\
100 & 100 & 100 \\
500 & 27 & - \\
1000 & 7.7 & 75.6 \\
\hline
\end{tabular}

Epididymides from lizards castrated at stage 1 and killed 1 month later were cultured for 10 days in the presence of various concentrations of testosterone or R1881. Total RNA was prepared, spotted onto nitrocellulose and hybridized with the Lv132 and Lv115 cDNA probes. The autoradiographs were scanned as described in 'Materials and Methods'. The absorbance values obtained with the Lv132 probe were corrected using the Lvl15 values to standardize the loading. All values are means of 2 separate experiments.

To determine whether other steroid hormones are able to induce Lv132 mRNA, explants from lizards castrated at stage 1 were cultured in the presence of oestradiol, progesterone or corticosterone, alone or in combination with testosterone at a concentration of $100 \mathrm{nM}$ (Table 2). Oestradiol and progesterone, alone or in combination with testosterone, had no effect on the Lv132-mRNA levels. Treatment of explants with corticosterone alone resulted in an induction of the mRNA accumulation similar to that observed with testosterone. Corticosterone and testosterone, when added simultaneously, increased the Lv132 mRNA concentrations $2 \cdot 6$-fold above the level observed with testosterone alone.

When epididymides at stage 10 (epithelium with only reserve cells) are cultured in the presence of corticosterone alone, no effect on the Lv132 mRNA level was observed (Table 2). However, synergism was obtained when tested with testosterone.

Stage 6 epididymides have been used in order to prepare crude extracts of cytoplasmic androgen receptors. At this stage, the androgen hormone concentrations are at their maximal levels and the principal cells are hypertrophied. $\left[{ }^{3} \mathrm{H}\right] \mathrm{R} 1881$ was able to bind with high affinity and Scatchard analysis was compatible with the presence of a single class of saturable binding sites $(y=-1 \cdot 1 x+$ $0.126, r=-0.941$ ) (Fig. 2). The apparent dissociation constant $\left(K_{\mathrm{d}}\right)$ of $\left[{ }^{3} \mathrm{H}\right] \mathrm{R} 1881$ was $0.9 \mathrm{nM}$ with a binding capacity of $85 \mathrm{fmol} / \mathrm{mg}$ cytosol protein. Table 3 shows the competition by various unlabelled steroids for binding of $\left[{ }^{3} \mathrm{H}\right] \mathrm{R} 1881$. R1881, DHT, testosterone and cyproterone acetate greatly inhibited $\left[{ }^{3} \mathrm{H}\right] \mathrm{R} 1881$ binding. In these experimental conditions, oestradiol and progesterone were able to bind to the androgen receptor, because an inhibition of the $\mathrm{R} 1881$ binding was observed in the presence of these hormones (69\% and $54 \%$ respectively). Only corticosterone produced a weak inhibition $(11 \%)$ in our conditions.

\section{Discussion}

Lv132-mRNA accumulation is androgen-dependent in epididymides from lizards castrated at stage 1 , as demonstrated by the effects of natural or synthetic androgens and an antiandrogen in the 
Table 2. Effects of various steroids on Lv132 mRNA accumulation in lizard epididymal explants

\begin{tabular}{lcc}
\hline \multirow{2}{*}{$\begin{array}{l}\text { Steroids } \\
(100 \mathrm{nM})\end{array}$} & \multicolumn{2}{c}{$\%$ Maximal induction } \\
\cline { 2 - 3 } & Stage 1 & Stage 10 \\
\hline None & 2 & $1 \cdot 9$ \\
Testosterone & 100 & 100 \\
Corticosterone & $99 \cdot 2$ & 2 \\
Corticosterone + testosterone & 266 & 206 \\
Progesterone & 2.9 & - \\
Progesterone + testosterone & 93.6 & - \\
Oestradiol & $3 \cdot 1$ & - \\
Oestradiol + testosterone & $95 \cdot 5$ & - \\
\hline
\end{tabular}

Explants removed at stage 10 or 1 month after castration at stage 1 were cultured for 10 days. Total RNA was prepared, spotted onto nitrocellulose and hybridized with the Lv132 and Lv115 cDNA probes. The autoradiographs were scanned and the absorbance values obtained with the Lvl 32 probe were corrected using the Lv1 15 values to standardize the loading. All values are means of 2 separate experiments.

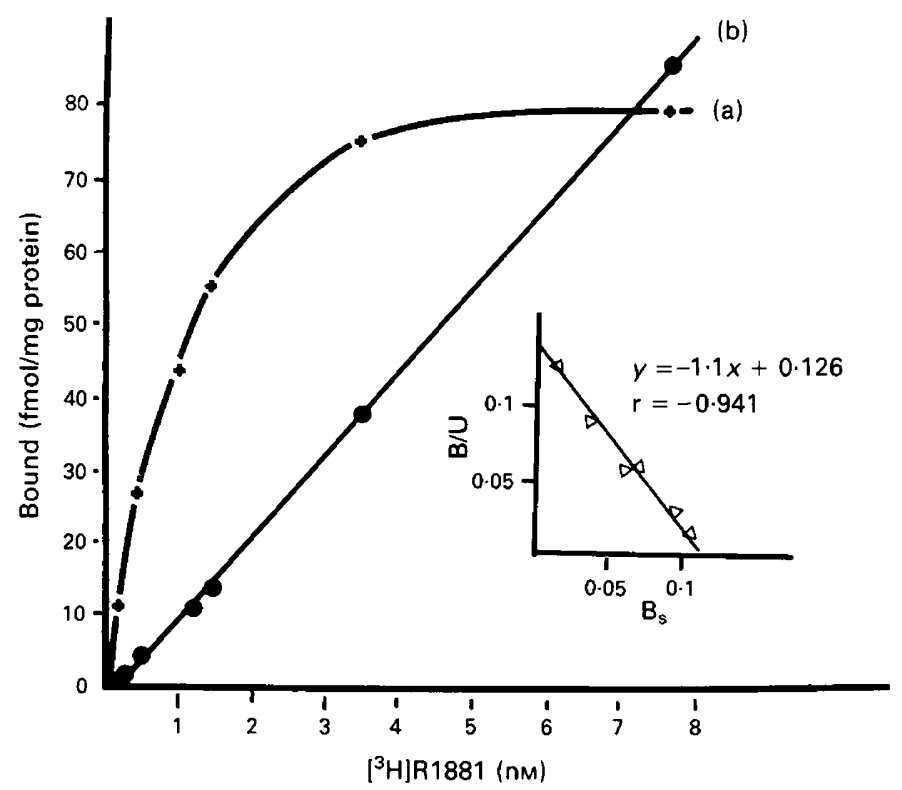

Fig. 2. Saturation analysis of $\left[{ }^{3} \mathrm{H}\right] \mathrm{R} 1881$ binding in the epididymis of lizards at stage 6 . Homogenate was incubated with increasing concentrations of $\left[{ }^{3} \mathrm{H}\right] \mathrm{R} 1881$ for $18 \mathrm{~h}$ at $4^{\circ} \mathrm{C}$. Bound and free fractions were separated by the hydroxylapatite method. Non-specific binding (b) was determined in the presence of a 100 -fold excess of non-radioactive hormone and was subtracted from total binding to give specific (a) binding. A Scatchard plot of the same data is shown. $K_{\mathrm{d}}=0.9 \mathrm{nM} ; \mathrm{B}_{\max }=85 \mathrm{fmol} / \mathrm{mg}$ protein; $\mathrm{B} / \mathrm{U}=$ bound to unbound ratio. 
- Table 3. Binding specificity of $\left[{ }^{3} \mathrm{H}\right] \mathrm{R} 1881$ to the androgen receptor in lizard epididymis

\begin{tabular}{lcc}
\hline Steriods & $\begin{array}{c}\text { Bound } \\
\text { (fmol/mg } \\
\text { protein) }\end{array}$ & $\begin{array}{c}\text { Inhibition } \\
(\%)\end{array}$ \\
\hline None & 135 & - \\
R1881 & $16 \cdot 2$ & 88 \\
DHT & $19 \cdot 2$ & $85 \cdot 7$ \\
Testosterone & $20 \cdot 2$ & $85 \cdot 2$ \\
Cyproterone acetate & $25 \cdot 7$ & 81 \\
Oestradiol & $41 \cdot 9$ & 69 \\
Progesterone & $62 \cdot 1$ & 54 \\
Corticosterone & $120 \cdot 2$ & 11 \\
\hline
\end{tabular}

Hormonal specificity was determined by measuring binding of $15 \mathrm{nM}-\left[{ }^{3} \mathrm{H}\right] \mathrm{R} 1881$ in the presence of a 100 -fold excess of various non-radioactive competitors. Bound and free hormone were separated by the hydroxylapatite method. Each value represents the mean of 2 measurements.

organ culture medium. In the absence of steroid hormones, the Lv132 mRNA is not expressed. Testosterone and R1881 at $100 \mathrm{~nm}$ stimulated accumulation of Lv132 mRNA, but testosterone at $10 \mathrm{nM}$ concentration was less efficient than R1881. This could be explained by a difference in the available concentrations of the active steroid. Unlike testosterone, R1881 is not metabolized in the cells, and is not bound to the sex binding proteins present in the fetal calf serum used in the media for the organ cultures. At testosterone concentrations higher than $100 \mathrm{nM}, \mathrm{Lv} 132 \mathrm{mRNA}$ accumulation was inhibited, but identical concentrations of R1881 continued to stimulate the Lv132 mRNA close to the maximal level. We suggest that the inhibitory effect observed with testosterone is not the consequence of saturation of the androgen receptor concentrations because similar binding kinetics have been observed with both steroids. The origin of this phenomenon remains unclear. However, an inhibitory effect mediated by a testosterone metabolite remains a possible explanation.

Like testosterone, corticosterone induced an accumulation of Lv132 mRNA in epididymides from lizards castrated at stage 1. In consequence, both hormones could activate specific gene expression in the lizard epididymis. Generally, in differentiated cells, steroid hormones can increase the levels of specific RNAs by altering the transcriptional rate of their genes. This regulation is thought to occur through the interaction of steroid-receptor complexes with discrete nucleotide sequences located in the $5^{\prime}$ regulatory regions of inducible genes (Yamamoto, 1985; Evans, 1988). Two different steroid hormones could act in a synergistic manner through the interaction of their corresponding receptors with two different sites adjacent or overlapping each other (Ankenbauer $e t$ $a l ., 1988)$. This kind of direct control is independent of protein synthesis. By contrast, the hormonal induction of some other RNAs is dependent on ongoing protein synthesis. These inductions can appear as a secondary action of the hormone (Vannice et al., 1984; Berger et al., 1985; Logsdon et al., 1987). In this study, we could not determine whether the inductions by testosterone and corticosterone are the consequence of direct or indirect actions of these hormones on the Lv132 gene.

Unlike testosterone, corticosterone alone had no effect on the accumulation of Lv132 mRNA in epithelium containing only reserve cells at the onset of culture (stage 10), although a synergistic effect was observed in the presence of testosterone. These observations suggest that testosterone promotes the differentiation of principal cells from reserve cells during the culture time and that a primary action of testosterone is necessary to confer corticosterone responsiveness on this tissue. 
Moreover, the primary effects of testosterone could be memorized because the corticosterone responsiveness persists after androgen deprivation. Experiments with rat prostate have suggested that primary epithelial responses to androgens may be regulated in large part by trophic factors secreted from stromal cells (Cunha et al., 1983). In our experiments whole epididymides were cultured, and so we cannot discount the possibility that stromal cells are the site of the primary action of testosterone or that these cells are the target of corticosterone. In these cases, the remembrance of the primary effects of androgens after castration could be explained by a stability of the imprinted cells and/or of their trophic factors. By contrast, the number of the epithelial cells is greatly enhanced even after castration. If androgens promote directly the differentiation of principal cells from the reserve cells, their primary effects must be propagated, in the absence of androgens, from the initial principal cells present at stage 1 to their descendants. Such a phenomenon of propagation of primary effects has been described in another steroid-dependent system (Zaret \& Yamamoto, 1984).

In the rat, glucocorticosteroids regulate the lipid levels of the epididymis (Balasubramanian $e t$ al., 1987); the mechanism involved in this action has not yet been elucidated. However, a mineralocorticoid receptor with a high affinity for corticosterone has been identified (Pearce et al., 1986). In the lizard, the effects of corticosterone are not dependent on the androgen receptor as shown by competition studies using R1881 as ligand.

In the rabbit epididymis, oestradiol affects protein synthesis (Toney \& Danzo, 1989). Among reptiles, oestrogen-binding activities have been detected in the epididymis of the viviparous lizard (Dufaure \& Chambon, 1978) and the turtle, Chrysemis picta (Dufaure et al., 1983). Nevertheless, oestradiol is ineffective in controlling the concentrations of Lv132 mRNA.

In conclusion, the expression of genes coding for secretory proteins starts before the maturation phase of the principal cells in mammals (Brooks, 1987; Charest et al., 1989) and the lizard (Courty et al., 1989). The present results show that the genetic switches leading to terminal differentiation of the reserve cells are strictly androgen-dependent. Furthermore, these switches allow extracellular signals other than androgens to co-regulate a specialized epithelial function. In the rat prostate, additive effects of testosterone and corticosterone upon prostatein synthesis have been described (Martikainen et al., 1987). These results, taken together with our findings, suggest that corticosteroids play a role in regulation of the function of the reproductive organs.

I thank Professor J. P. Dufaure and Professor G. Veyssière for support; and Dr E. Melanitou for critical reading of the manuscript. This work was supported by a grant from the Fondation pour la Recherche Médicale française.

\section{References}

Abou-Aila, A. \& Fain-Maurel M.A. (1986) Postnatal differentiation of the enzymatic activity of the mouse epididymis. Int. J. Androl. 8, 441-458.

Ankenbauer, W., Strähle, U. \& Schütz, B. (1988) Synergistic action of glucocorticoid and estradiol responsive elements. Proc. natn. Acad. Sci. USA 85, $7526-7530$.

Balasubramanian, K., Aruldhas, M.M. \& Govindarajuhu, P. (1987) Effect of corticosterone on the rat epididymal lipids. J. Androl. 8, 69-73.

Berger, G.F., Loose, D., Meisner, D.L. \& Watson, G. (1985) Androgen induction of messenger RNA concentrations in mouse kidney is post-transcriptional. Biochemistry, $N Y 26,1170-1175$.

Brandt, H., Acott, T.S., Johnson, D.J. \& Hoskins, D.D. (1978) Evidence for an epididymal origin of bovine sperm motility protein. Biol. Reprod. 19, 830-835.

Brooks, D.E. (1987) Developmental expression and androgenic regulation of the mRNA for major secretory proteins in rat epididymis. Molec. cell. Endocrinol. 53, 59-66.

Brooks, D.E. \& Tiver, K. (1983) Location of epididymal secretory proteins on rat spermatozoa. J. Reprod. Fert. 69, 651-657.

Cathala, S., Savouret, J.F., Mendez, B., West, B.C., Karin, M., Martial, J.A. \& Baxter, J.D. (1983) A method for isolation of intact translationally active ribonucleic acid. DNA 2, 329-335.

Charest, N.J., Petruz, P., Ordronneau, P., Joseph, D.R., Wilson, E.M. \& French, F.S. (1989) Developmental expression of an androgen-regulated epididymal protein. Endocrinology 125, 942-947.

Courty, Y., Morel, F., Ravet, V. \& Dufaure, J.P. (1989) Molecular cloning of two cDNAs for related secretory proteins in lizard epididymis: gene expression during androgen-induced cell growth and secretion. Molec. cell. Endocrinol. 62, 55-67. 
Cuasnicu, P.S., Gonzalez Echeverria F., Piazza, A. \& Blaquier J.A. (1984) Addition of androgens to cultured hamster epididymis increases zona recognition by immature spermatozoa. $J$. Reprod. Fert. $\mathbf{7 0 ,}$ 541-547.

Cunha, G.R., Chung, L.W.K., Shannon, J.M., Tagucchi, O. \& Fujii, H. (1983) Hormone-induced morphogenesis and growth: role of mesenchyme-epithelial interaction. Recent Prog. Horm. Res. 39, 559-595.

Depeiges, A. \& Dacheux, J.L. (1985) Acquisition of sperm motility and its maintenance during storage in the lizard, Lacerta vivipara. J. Reprod. Fert.74, 23-27.

Depeiges, A. \& Dufaure, J.P. (1981) Major proteins secreted by the epididymis of Lacerta vivipara: identification by electrophoresis of soluble proteins. Biochim. Biophys. Acta 667, 260-266.

Depeiges, A. \& Dufaure, J.P. (1983) Binding to spermatozoa of major soluble protein secreted by the epididymis of the lizard, Lacerta vivipara. Gamete Res. 4, 401-406.

Depeiges, A., Betail, G. \& Dufaure, J.P. (1981) Time course of appearance in-vivo and in-vitro of a specific epididymal protein controlled by testosterone. Biol. Cell. 42, 49-56.

Depeiges, A., Morel, F. \& Dufaure, J.P. (1988) Identification of an epididymal immunorelated protein family, sequential appearence under testosterone stimulation. Biochim. Biophys. Acta 964, 383-387.

Dufaure, J.P. \& Chambon, M. (1978) Etude histoautoradiographique d'un organe cible de la testosterone, l'épididyme de lézard après administration de $17 \beta-$ estradiol- ${ }^{3}$ H. C. r. Séanc. Soc. Biol. 172, $1127-1130$.

Dufaure, J.P., Mak, P. \& Callard, I.P. (1983) Estradiol binding activity in epididymal cytosol of the turtle, Chrysemis picta. Gen. comp. Endocrinol. 51, 61-65.

Dufaure, J.F., Courty, Y., Depeiges, A., Mesure, M. \& Chevalier, M. (1986) Evolution and testosterone content of the epididymis during the annual cycle of the lizard Lacerta vivipara. Biol. Reprod. 35, 667-675.

Evans, R.M. (1988) Steroid and thyroid hormone receptors as transcriptional regulators of development and physiology. Science, NY 240, 889-895.

Hechter, O., Mechaber, D., Zwick, A., Campfield, I.A., Eychenne, B., Baulieu E.E. \& Robel, P. (1983) Optimal radioligand exchange conditions for measurement of occupied androgen receptor sites in ventral prostate. Archs Biochem. Biophys. 224, 49-68.

Klinefelter, G.R. \& Hamilton, D.W. (1985) Synthesis and secretion of proteins by perifused caput epididymal tubules and association of secreted proteins with spermatozoa. Biol. Reprod. 33, 1017-1027.

Logsdon, C.D., Perot, K.J. \& McDonald, A.R. (1987) Mechanism of glucocorticoid-induced increase in pancreatic amylase gene transcription. J. biol. Chem. 262, 15765-15769.

Martikainen, P., Harkonen, P., Vanhala, T., Makela, S., Viljanen, M. \& Suominen, J. (1987) Multihormonal control of synthesis and secretion in cultured rat ventral prostate. Endocrinology 121, 604-611.

Moore, H.D.M. \& Hartman, T.D. (1986) In-vitro development of the fertilizing ability of hamster epididy- mal spermatozoa after co-culture with epithelium from the cauda epididymidis. J. Reprod. Fert. 78, 347-352.

Morel, F., Courty, Y., Mesure, M. \& Dufaure, J.P. (1986) Effects of castration on the epididymis of a nonmammalian vertebrate: evolution of morphology, protein synthesis and of specific mRNA levels. Biol. Cell. 58, 201-210.

Morel, F., Courty, Y., \& Dufaure, J.P. (1988) Effects of differentiation state and post-castration time lapse on the epididymal response of the lizard to testosterone in-vitro: changes in specific protein and mRNA levels. Int. J. Androl. 11, 349-360.

Orgebin-Crist, M.C. \& Jahad, N. (1978) The maturation of rabbit epididymal spermatozoa in organ culture: inhibition by antiandrogens and inhibitors of ribonucleic acid and protein synthesis. Endocrinology $103,46-53$.

Pearce, P.T., Lipkevicius, D.R. \& Funder, J.W. (1986) High affinity (type I) aldosterone-binding sites in rat epididymis. Endocrinology 118, 2072-2075.

Ravet, V., Courty, Y., Depeiges, A. \& Dufaure, J.P. (1987) Changes in epididymal protein synthesis during the annual cycle of the lizard Lacerta vivipara. Biol. Reprod. 37, 901-907.

Sun, E.L. \& Flickinger, C.J. (1979) Development of cell types and of regional differences in the postnatal rat epididymis. $J$. Anat. 154, 27-56.

Thomas, T.S., Reynolds, A.L.B. \& Oliphant, G. (1984) Evaluation of the site of synthesis of rabbit sperm acrosome stabilizing factor using immuno-cytochemical and metabolic labeling techniques. Biol. Reprod. $\mathbf{3 0}$, 693-705.

Toney, T.W. \& Danzo, B.J. (1989) Estrogen and androgen regulation of protein synthesis by the immature rabbit epididymis. Endocrinology 125, 231-242.

Turner, T.T. \& Reich, G.W. (1987) Influence of proteins in rat cauda epididymal lumen fluid on cauda sperm motility. Gamete Res. 18, 267-278.

Vannice, J.L., Taylor, J.M. \& Ringold, G.M. (1984) Glucocorticoid-mediated induction of a acid-glycoprotein: evidence for hormone-regulated RNA processing. Proc. natn. Acad. Sci. USA 81, 4241-4245.

Veyssiere, G., Berger, M., Jean-Faucher, C., De Turkeim, M. \& Jean, C. (1985) Androgen receptor in genital tubercle of rabbit fetuses and newborns. Ontogeny and properties. J. Steroid Biochem. 23, 399.404.

Vogimayr, J.K., Fairbanks, G., Vespa, B.B. \& Colella, J.R. (1982) Studies on the mechanism of surface modification in ram spermatozoa during the final stages of differentiation. Biol. Reprod. 26, 483-500.

Yamamoto, K.R. (1985) Steroid receptor regulated transcription of specific genes and gene networks. Annu. Rev. Genetics 19, 209-252.

Zaret, K.S. \& Yamamoto, K.R. (1984) Reversible and persistent changes in chromatin structure accompany activation of a glucocorticoid-dependent enhancer element. Cell 38, 29-38.

Received 21 May 1990 